\title{
Analysis of risk factors associated with hepatitis $B$ and $C$ infection in correctional institutions in British Columbia
}

RG PRÉFONTAINE MD, RK CHAUDHARY PhD Dip BaCt, RG MATHIAS MD

RG Préfontaine, RK Chaudhary, RG Mathias. Analysis of risk factors associated with hepatitis B and $C$ infection in correctional institutions in British Columbia. Can J Infect Dis 1994;5(4):153-156. The factors associated with infection with hepatitis B (HBV) and C viruses (HCV) were studied in residents of correctional institutions in British Columbia. Four hundred and fifteen residents volunteered to participate in this study. Among 415 residents tested, $28 \%$ were positive for HVB or HCV markers. Sixty-five per cent of the residents positive for $\mathrm{HBV}$ markers were also infected with $\mathrm{HCV}$. However, in HBV-negative residents, only $14 \%$ were positive for antibody to HCV (anti-HCv). The highest rates for HBV and HCV were in 25- to 44-year-old residents. The analysis of risk factors and infection predictors in 354 residents showed that intravenous drug use and history of hepatitis were associated with infection with both HBV and HCV. The relative risk for HBV in intravenous drug users was 4.4 times that in nonusers; for HCV relative risk was 3.4 times. In the group with history of hepatitis, the relative risk was 6.2 and 4.5 times for HBV and HCV, respectively. The multivariate analysis of the data showed that both intravenous drug use and a history of hepatitis were significant $(\mathrm{P}<0.0001)$. Tattooing or history of transfusion was not associated with increased risk for HCV. but tattooing and age were significant factors for HBV.

Key Words: Hepatitis B virus, Hepatitis C virus, Risk factors

\section{Analyse des facteurs de risque associés à l'hépatite B et à l'hépatite C dans les établissements correctionnels de la Colombie-Britannique}

RÉSUMÉ : Les facteurs associés à l'infection au virus de l'hépatite B et de l'hépatite C (HBV et HCV) ont été étudiés chez des prisonniers incarcérés dans des établissements correctionnels de la Colombie-Britannique. Quatre cent quinze résidents se sont portés volontaires pour participer à cette étude. Parmi les 415 résidents soumis aux analyses, $28 \%$ se sont révélés séropositifs à l'égard des marqueurs du virus de l'hépatite B ou C. Soixante-cinq pour cent des résidents séropositifs à l'égard des marqueurs du HBv étaient également infectés au HCV. Toutefois, chez les résidents HBV-négatifs, seuls 14 \% étaient positifs à l'égard de l'anticorps anti-HCV. Les taux les plus élevés à l'égard du HBV et du HCV se trouvaient dans la tranche des 25 à 44 ans. L'analyse des facteurs de risque et des prédicteurs de l'infection chez 354 résidents a révélé que la prise de drogues intraveineuses et les antécédents d'hépatite étaient autant associés à l'infection par HBV que par HCV. Le risque relatif de HBV chez les usagers de drogues intraveineuses était de 4,4 fois plus élevé que chez les non-utilisateurs. Pour le HCv, le risque relatif à l'égard du HBV était de 3,4

Correctional Services of Canada, Abbottsford. British Columbia; Laboratory for Viral Hepatitis, Bureau of Microbiology.

Laboratory Centre for Disease Control, Health Canada, Ottawa; and Department of Health Care and Epidemiology, University of British Columbia, Vancouver. British Columbia

Correspondence and reprints: Dr RK Chaudhary, Laboratory for Viral Hepatitis, Bureau of Microbiology, Laboratory Centre for Disease Control, Tunney's Pasture, Ottawa, Ontario K1A OL2. Telephone (613) 957-0180, Fax (613) 954-0207

Received for publication December 21, 1993. Accepted April 4, 1994 
fois plus élevé. Dans le groupe présentant des antécédents d'hépatite, le risque relatif était de 6,2 et de 4,5 fois, pour le HBV et le HCV respectivement. L'analyse à variables multiples des données a révélé que, et les drogues intraveineuses et les antécédents d'hépatite étaient significatifs $(\mathrm{P}<0,0001)$. Le tatouage ou les antécédents de transfusion n'ont pas été associés à un risque accru de HCV, mais le tatouage et l'âge ont été des facteurs significatifs à l'égard du HBV.

$\mathrm{T}$ HE INTRODUCTION OF A NEW TEST FOR THE DETECTION OF antibody to hepatitis C virus (anti-HCV) has allowed the study of infection with this virus in different risk groups (1). A high prevalence of hepatitis C virus (HCV) infection has been reported in hemodialysis patients (2), intravenous drug users (3) and hemophiliacs (4). Several studies (5-8) have shown that there is a high prevalence of infection with hepatitis B virus (HBV) in residents of correctional institutions. Recent studies have also shown a high prevalence of infection with HCV in residents of correctional institutions (9-11). However, in these studies, the associated factors were not investigated.

We report here the analysis of the factors associated with the seroprevalence of $\mathrm{HBV}$ and $\mathrm{HCV}$ in residents of federal correctional institutions in British Columbia.

\section{PATIENTS AND METHODS}

In 1989 Correctional Services of Canada implemented a hepatitis B immunization program for all inmates incarcerated in federal institutions. In the Pacific region (British Columbia and Yukon), where $14.4 \%$ of federal inmates are incarcerated, a seroprevalence study for viral hepatitis markers was undertaken as part of the immunization program. The initial phase of the program was to provide the inmate population with information on the potential short term and long term effects of hepatitis B infection and the benefits of immunization. Information brochures were distributed, audiovisual presentations and group and individual counselling were given. In the first six months of the program, $23 \%$ of the population accepted the invitation to participate in the immunization program. Informed consent was obtained from all participants before immunization with hepatitis $B$ vaccine and screening for viral hepatitis markers. Providing a blood sample or completion of a questionnaire designed to identify predictor (ie, history of hepatitis) and risk factors was not mandatory for immunization. The questionnaire requested information on history of hepatitis, blood transfusions, tattooing, intravenous drug use and sexual orientation.

Blood samples were obtained from 415 male residents of the federal correctional institutions in British Columbia. The number of residents tested from each age group and sampling rates are given in Table 1 . Samples were tested for hepatitis B surface antigen (HBsAg), antibody to core antigen (anti-HBc) and antibody to surface antigen (anti-HBs) by enzyme immunoassays (Abbott Laboratories, Illinois). These samples were stored at $-70^{\circ} \mathrm{C}$ and later tested for anti-HCv by enzyme
TABLE 1

Sampling rate of residents in British Columbia correctional institutions

\begin{tabular}{lccccc}
\hline & \multicolumn{5}{c}{ Age groups (years) } \\
Categories & $15-24$ & $25-34$ & $35-44$ & $45-54$ & $>55$ \\
\hline $\begin{array}{l}\text { Total population } \\
\quad(1806)\end{array}$ & 290 & 769 & 498 & 164 & 85 \\
$\begin{array}{l}\text { Number tested (415) } \\
\text { Response rate (\%) }\end{array}$ & 50 & 174 & 117 & 43 & 30 \\
\hline
\end{tabular}

immunoassay. The anti-HCV repeat positive samples were further tested by first-generation recombinant immunoblot assay (RIBA) HCV (Ortho Diagnostics Inc, New Jersey). The RIBA HCV indeterminate samples were later tested by second-generation RIBA HCV test.

An individual was infected with HBV if he or she was HBsAg-positive and/or anti-HBc-positive. Individuals who were anti-HBs-positive only were not included in the infected group. A positive result for anti-HCV was defined as a positive enzyme immunoassay plus a positive confirmatory test. Data were entered in a computer file without individual identifiers. Analysis was carried out using $\chi^{2}$ or multivariate analysis using logistic regression.

\section{RESULTS}

Four hundred and fifteen inmates consented to have blood drawn. There were 1806 eligible for the study (Table 1). The questionnaires were completed by 354 $(85.3 \%)$ of 415 participating residents. The sampling rates were similar for the older groups at 23 to $35 \%$ but lower in the 15 to 24 age group at $17 \%$. Twelve residents $(3.0 \%)$ were positive for HBsAg (Table 2 ). The prevalence of HBV markers was $28 \%$. None of the inmates had been immunized with HBV vaccine to the authors' knowledge but three were positive for anti-HBs alone, which may represent immunization.

The prevalence of anti-HCV was also high, with 106 samples (25.5\%) positive by both enzyme immunoassay and first generation RIBA HCV tests. Of 10 samples that were indeterminate by first generation RIBA HCV, nine were positive by second-generation RIBA; thus, the overall prevalence of anti-HCV was $28 \%$ in this population.

The distribution of markers (Table 2) showed that 259 residents were negative, 41 were HBV-positive and HCV-negative, 37 were anti-HCV-positive and HBV-negative and $76(65 \%)$ were positive for both. Results showed that residents positive for HBV or HCV alone had somewhat different distributions of risk factors. Intravenous drug use was a risk factor in $76 \%$ of anti-HCV 
TABLE 2

Prevalence and relationship of HBV markers and anti$\mathrm{HCV}$ in the residents of Brisith Columbia correctional services

\begin{tabular}{lc}
\hline & Number (\%) \\
\hline Total samples tested & 415 \\
Positive for HBsAg & $12(3)$ \\
Positive for HBV markers & $117(28)$ \\
Positive for anti-HCV & $115(28)$ \\
Positive for both & $76(65)$ \\
Negative for both & $259(62)$ \\
HBV-positive HCV-negative & $41(10)$ \\
HCV-positive HBV-negative & $37(9)$ \\
\hline
\end{tabular}

HBsAg Hepatitis B surface antigen: HBV Hepatitis B virus; HCV Hepatitis C virus

TABLE 3

Predictive factors for the prevalence of hepatitis B and hepatitis $C$ viruses

\begin{tabular}{|c|c|c|c|c|c|c|c|}
\hline \multirow[b]{2}{*}{ Risk factors } & & \multicolumn{3}{|c|}{ Hepatitis B } & \multicolumn{3}{|c|}{ Hepatitis C } \\
\hline & & Rate/ 100 & RR & $95 \% \mathrm{CL}$ & Rate/ 100 & RR & $95 \% \mathrm{Cl}$ \\
\hline Intravenous drug use & $\begin{array}{l}\text { With } \\
\text { Without }\end{array}$ & $\begin{array}{l}50 \\
11\end{array}$ & 4.4 & $2.9-6.7$ & $\begin{array}{l}83 \\
24\end{array}$ & 3.4 & $2.7-4.3$ \\
\hline Transfusion & $\begin{array}{l}\text { With } \\
\text { Without }\end{array}$ & $\begin{array}{l}21 \\
21\end{array}$ & 1 & $0.64-1.6$ & $\begin{array}{l}22 \\
20\end{array}$ & 1.1 & $0.68-1.7$ \\
\hline
\end{tabular}

CL Confidence limits; RR Relative risk

and $45 \%$ of HBV-positive residents. Tattooing was a risk factor for HBV (18\%) but not for anti-HCV-positive (5\%) residents. Transfusion was a small risk factor for antiHCV-positive residents only (data not shown).

The positivity rate for HBV markers and anti-HCV for different age groups is given in Figure 1. Results showed that the rate for HBV (18\%) and HCV (16\%) was similar in the 15 to 24 year age group, with a small percentage (4\%) of individuals infected with both. In the 25 to 34 year age group, the infection rates for HBV, HCV and dual infection were 30,32 and $22 \%$, respectively. The rate for HBV was further increased to $38 \%$ in the 35 to 44 year age group, whereas the prevalence of anti$\mathrm{HCV}(30 \%)$ decreased somewhat and the prevalence rate for dual infection remained the same (21\%). However, the rates for both $\mathrm{HBV}(16 \%)$ and $\mathrm{HCV}(16 \%)$ were significantly reduced in the 45 to 54 year age group. Dual infection was detected in $9 \%$ of the residents tested. There was a further decline in the prevalence of HBV markers (13\%) in residents 55 years of age or older. The prevalence of $\mathrm{HCV}(3 \%)$ was also significantly reduced. The dual infection rate in this group was $1 \%$.

Of the 415 residents, 354 completed questionnaires regarding risk factors. Having a history of hepatitis was a strong predictor of having HBV markers, (relative risk $[R R]=6.2,95 \%$ confidence limits [CL] 3.5-11.2) or HCV markers (RR=4.5 95\% CL 2.6-8.0) (Table 3). Of the risk

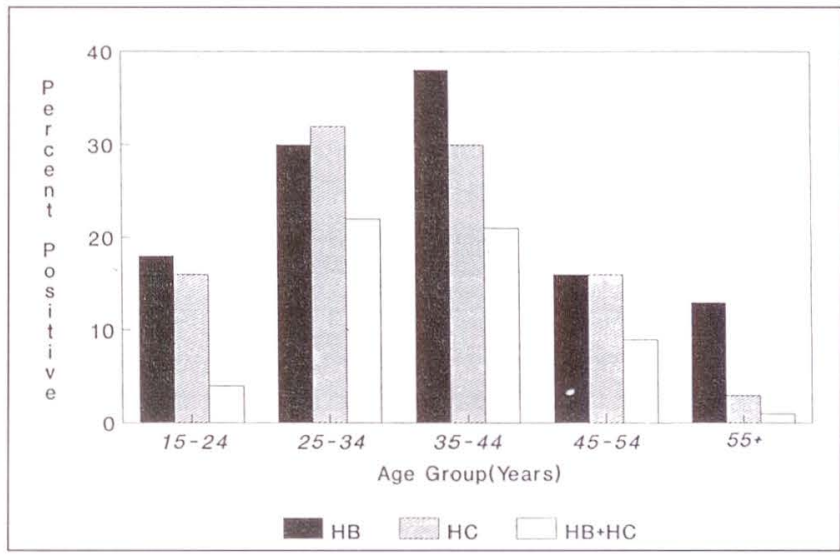

Figure 1) Prevalence rates of hepatitis $B(H B)$ virus, hepatitis $C$ (HC) virus and both in different age groups of residents of British Columbia correctional institutions 
tested. As this was part of an immunization program, the prevalences may be low because immunization was not available for those who had been infected previously. In spite of this, similar data have been reported previously by other investigators (5-8) for HBV. Intravenous drug use has been found to be important for HBV infection (8,11-13); however, the risk factors associated with HCV infection in residents of correctional institutions has not been fully explored. The comparison of risk factors for HBV-positive with those for $\mathrm{HCV}$-positive individuals may give some information on the relative infectivity of routes of infection.

Twenty-eight per cent of residents were positive for anti-HCV. A similar prevalence rate $(29.8 \%)$ was reported (9) from another institution in Canada. The risk factor associated with HCV infection is intravenous drug use. Intravenous drug use has been recognized previously as an important risk factor (14) for infection with HCV. History of hepatitis was also a predictive factor for infection with HCV. However, the significance of this factor is that, in the event of an exposure to the blood of a person with history of hepatitis, that exposure is much more likely to be to $\mathrm{HBV}$ or $\mathrm{HCV}$ than in an individual without such a history, at least in this population.

Transfusion, age and tattooing were not associated with increased risk for infection with HCV. A recent report (14) from the United States also indicated that the majority of HCV infections was not associated with transfusion. That transfusion is not a risk factor is possibly due to screening of blood donation for $\mathrm{HCV}$. Our results indicate that there is a relationship between HBV and $\mathrm{HCV}$ transmission as $65 \%$ of $\mathrm{HBV}$-positive residents were also positive for $\mathrm{HCV}$. Hence the screening for HBV has

ACKNOWLEDGEMENTS: We thank Dr K Rozee for reviewing the manuscript and Mrs M Kanabe for secretarial help.

\section{REFERENCES}

1. Kuo G, Choo Q-L. Alter HJ, et al. An assay for circulating antibodies to a major etiologic virus of human non-A. non-B hepatitis. Science 1989;244:362-4.

2. Jeffers LJ, Perez GO, DeMedina MD, et al. Hepatitis C infection in two urban haemodialysis units. Kidney Int 1990;38:320-2.

3. VandenHoek JAR, VanHaastrecht HJA, Goudsmit J, et al. Prevalence incidence and risk factors of hepatitis C virus infection among drug users in Amsterdam. J Infect Dis 1990; 162:823-6.

4. Makris M, Preston FE, Triger DR, et al. Hepatitis C antibody and chronic liver disease in haemophilia. Lancet 1990;335:1117-9.

5. Kibby T, Devine J, Love C. Prevalence of hepatitis B among men admitted to a federal prison. N Engl J Med 1982;306:175.

6. Chiaramonte M, Trivello R, Renzulli G, et al. Hepatitis B virus infection in prisons: A seroepidemiological survey in prisoners and attending staff. J Hyg Camb 1982:89:53-8.

7. Kaufman ML, Faiver KL, Harness JK. Hepatitis B markers among Michigan prisoners. Ann Intern Med 1983:98:558. also reduced the risk for HCV. The multivariate analysis showed that both intravenous drug use and history of hepatitis were significant for $\mathrm{HCV}$ infection $(\mathrm{P}<0.0001)$.

Another observation was of the coexistance of infection with HBV and HCV in a large proportion of residents $(65 \%)$ tested. A similar finding was also reported from Alberta, where $58 \%$ of HBV-positive inmates were also positive for HCV (1 1).

These results showed that HBV and HCV have some similar predictors such as intravenous drug use and history of hepatitis. However, some of the predictors are not shared, such as tattooing and age, which were risk predictors for HBV but not for HCV. A large proportion of anti-HCV-positive individuals carries the HCV virus $(14,15)$. Our results indicate that HCV may not be as infectious as HBV. The lack of an association with tattooing may indicate that needlestick exposures to $\mathrm{HCV}$ are not as likely to result in infection. The lack of association with age may indicate a cohort effect, but this also may be a marker for other risk factors such as sexual transmission.

Overall, the comparison of HCV with HBV risk predictors indicates that HCV is being transmitted to individuals in correctional institutions and intravenous drug use is the major risk factor. Tattooing, as carried out in institutions, is a risk factor for $\mathrm{HBV}$ but not $\mathrm{HCV}$, indicating that HCV may require larger amounts of fluid transfer for infection to occur and hence a lower risk of infection following needlestick exposures. There is a need to clarify the transmission routes for $\mathrm{HCV}$ in order to inform inmates and staff of potential risks. HCV appears to have similar risk factors to human immunodeficiency virus.

8. Decker MD, Vaughn WK, Brodie JS, et al. The incidence of hepatitis B in Tennessee prisoners. J Infect Dis 1985; 152:214-7.

9. Chaudhary RK, Mo T. Antibody to hepatitis C virus in risk groups in Canada. Can J Infect Dis 1992;3:27-9.

10. Préfontaine RG, Chaudhary RK. Seroepidemiologic study of hepatitis B and $\mathrm{C}$ viruses in federal correctional institutions in British Columbia. Can Dis Weekly Rep 1990;16-52:265-6.

11. Anand CM, Fonseca K, Walle RP, et al. Antibody to hepatitis $\mathrm{C}$ virus in selected groups of a Canadian urban population. Int J Epidemiol 1992;21:142-5.

12. Norkraus G, Frösner G, Hermodsson, et al. Multiple hepatitis attacks in drug addicts. JAMA 1980;243:1056-8.

13. Moestrup T, Hansson BG, Widell A, et al. Long term follow up of chronic hepatitis B virus infection in intravenous drug abusers and homosexual men. Br Med J 1986;292:854-7.

14. Alter MJ, Hadler SC, Judson FN, et al. Risk factors for acute non-A, non-B hepatitis in the United States and association with hepatitis $\mathrm{C}$ virus infection. JAMA 1990:264:2231-5.

15. Allain J-P, Coghlan PJ, Kenrick KG, et al. Prediction of hepatitis $\mathrm{C}$ virus infectivity in seropositive Australian blood donors by supplemental immunoassay and detection of viral RNA. Blood 1991;78:24628 


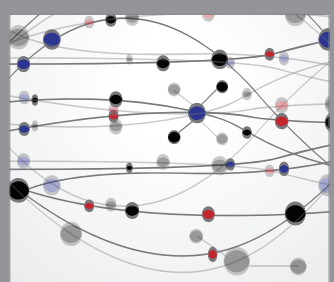

The Scientific World Journal
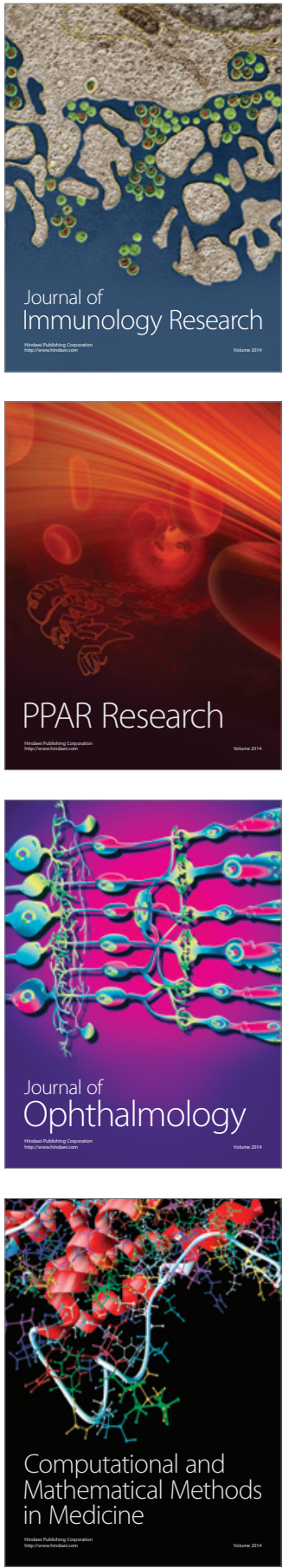

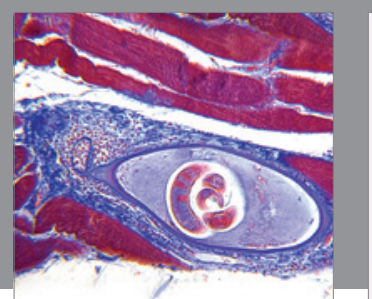

Gastroenterology Research and Practice

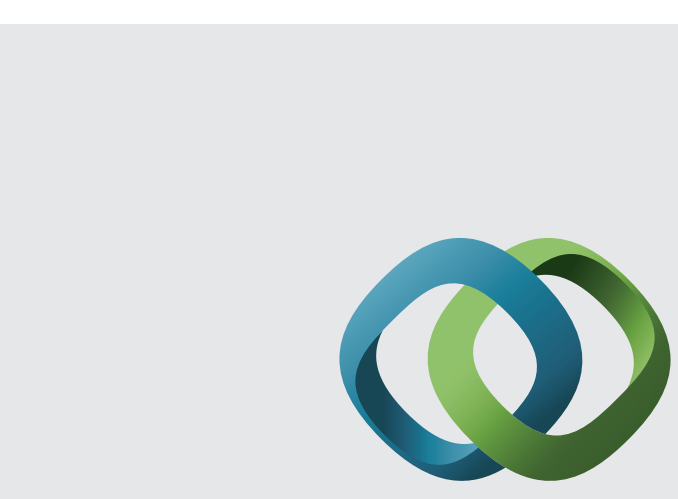

\section{Hindawi}

Submit your manuscripts at

http://www.hindawi.com
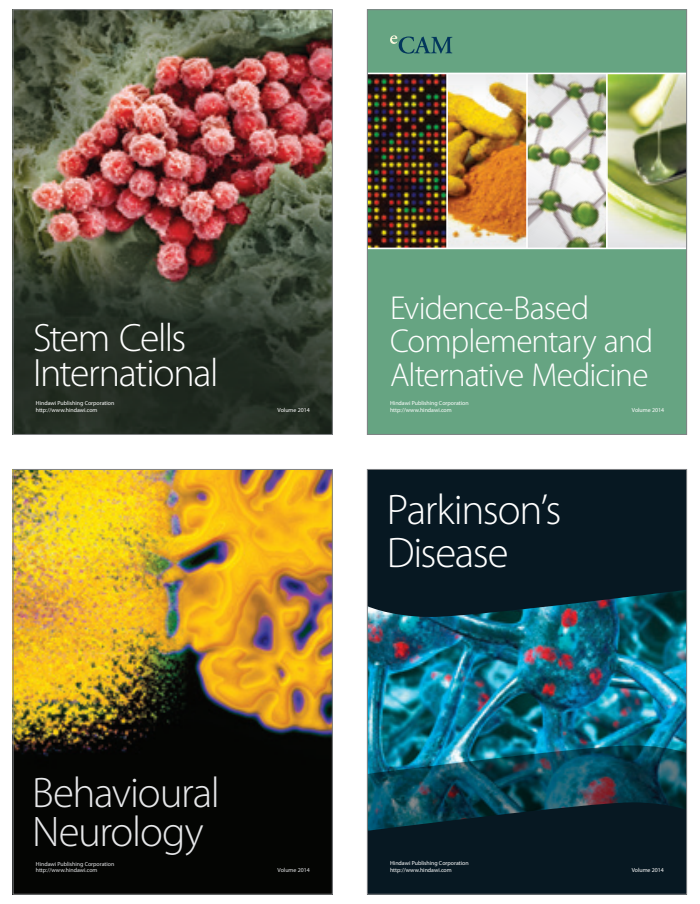
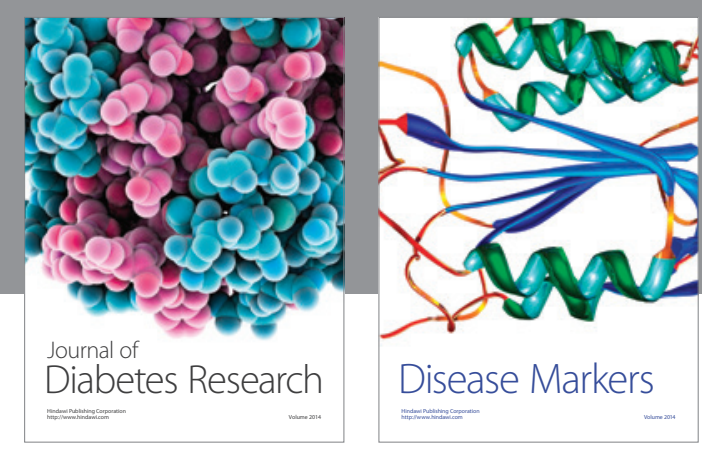

Disease Markers
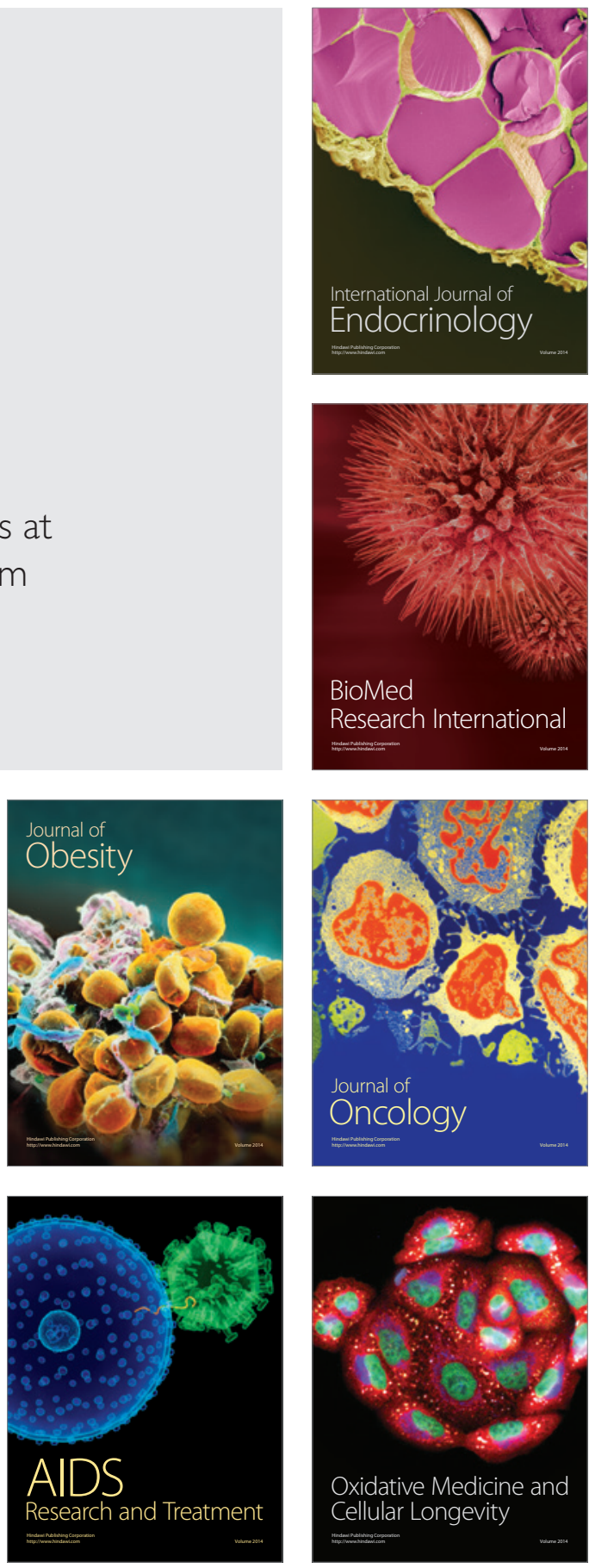